\title{
ECAP-TREATED ALUMINIUM ALLOY AA2030: MICROSTRUCTURE AND MECHANICAL PROPERTIES
}

\author{
EKSTREMNA PLASTIČNA DEFORMACIJA Al ZLITINE AA2030: \\ MIKROSTRUKTURA IN MEHANSKE LASTNOSTI
}

\author{
Violetta Andreyachshenko*, Yulianna Isheva, Aliya Mazhit, Dinara Imangazinova \\ Department for Power Engineering and Metallurgy, Ekibastuz Technical and Engineering Institute (Ekibastuz Technical and Engineering \\ Institute named after the academician K. Satpayev), 54A Energetikov Street, 141200 Ekibastuz, Kazakhstan
}

Prejem rokopisa - received: 2018-11-21; sprejem za objavo - accepted for publication: 2019-05-29

doi:10.17222/mit.2018.250

\begin{abstract}
The work deals with the effect of the ECAP treatment on the microstructure and mechanical properties of the AA2030 alloy. There were four cycles of deformation in the $105^{\circ}$-tool for pre-annealed samples, which ensured the preparation of an ultrafine-grained structure, both along the $\mathrm{Bc}$ route and along the $\mathrm{C}$ route. The average grain size after four cycles of ECAP was $420 \mathrm{~nm}$ for the samples treated along the Bc route and $380 \mathrm{~nm}$ for the samples treated along the $\mathrm{C}$ route. In the structure of the metal, there were inclusions of $\mathrm{A} 120 \mathrm{Cu} 2 \mathrm{Mn} 3$, the $\theta$-phase and $\mathrm{A} 17 \mathrm{Cu} 3 \mathrm{Fe}$. After three cycles of the ECAP treatment, the alloy was hardened by $54 \%$ along the $\mathrm{Bc}$ route and $60 \%$ along the $\mathrm{C}$ route compared with the annealed condition. The overall increase in the microhardness was $138 \%$ for the samples treated along the $\mathrm{Bc}$ route and $113 \%$ for the samples treated along the $\mathrm{C}$ route. Because of prolonged aging, the number of dispersoids increased at room temperature, long rod-like inclusions transformed into more favourable short ones with a length of up to $150 \mathrm{~nm}$, and partial dissolution of the $\theta$-phase was observed After the aging, the grain boundaries were predominantly equilibrium, thin, without the moire contrast, and a rearrangement of dislocation walls into subgrain boundaries was found. In addition, after the prolonged natural aging, large grains with non-equilibrium boundaries fragmented into subgrains with sizes of 100-300 nm.
\end{abstract}

Keywords: SPD, TEM, aluminium alloy AA2030, ECAP

Avtorji v članku opisujejo študijo vpliva ekstremne plastične deformacije, izvedene s postopkom enakokotnega kanalskega stiskanja (ECAP; angl.: equal-channel angular pressing) na mikrostrukturo in mehanske lastnosti Al zlitine tipa AA2030. Izvedli so štiri cikle deformacije predhodno žarjenih vzorcev v orodju s $105^{\circ}$ kotom. To je omogočilo pripravo zlitine po dveh standardnih ECAP postopkih (Bc in $\mathrm{C}$ ) z ultradrobnimi kristalnimi zrni. Povprečna velikost zrn po štirih ciklih plastične deformacije je bila $420 \mathrm{~nm}$ pri vzorcih obdelanih s postopkom Bc, in $380 \mathrm{~nm}$ pri vzorcih obdelanih s postopkom C. V mikrostrukturi obdelanih materialov so avtorji opazili vključke faz $\mathrm{Al}_{20} \mathrm{Cu}_{2} \mathrm{Mn}_{3}, \theta$-faze in $\mathrm{Al}_{7} \mathrm{Cu}_{3} \mathrm{Fe}$. Po treh ciklih izvedbe $\mathrm{Bc}$ postopka ECAP se je zlitina utrdila za $54 \%$ in $60 \%$, po postopku C glede na žarjeno stanje. Celokupno povečanje trdote je bilo $138 \%$ pri vzorcih izvedenih s postopkom Bc in $113 \%$ pri vzorcih obdelanih s postopkom C. Podaljšano staranje vzorcev pri sobni temperaturi je povzročilo povečanje števila izločkov, dolgi paličasti izločki so se pretvorili $\mathrm{v}$ manj kot $150 \mathrm{~nm}$ dolge in bolj zaželene izločke. Opazili so tudi delno raztapljanje $\theta$-faze. Po staranju so bile meje kristalnih zrn prednostno v ravnotežju, tanke, brez valovitega kontrasta in ugotovili so tudi preureditev sten dislokacij v meje podzrn. Dodatno je podaljšano naravno staranje pokazalo udrobljenje večjih kristalnih zrn z neravnotežnimi kristalnimi mejami v podzrna velikosti $100 \mathrm{~nm}$ do $300 \mathrm{~nm}$.

Ključne besede: ekstremna plastična deformacija (SPD), presevna elektronska mikroskopija (TEM), aluminijeva zlitina AA22030, enakokotno kanalsko stiskanje (ECAP)

\section{INTRODUCTION}

In recent decades, there has been a growing interest in ultrafine-grained (UFG) materials obtained with severe plastic deformation (SPD). ${ }^{1-3}$ The SPD processes provide for an accumulation of high-degree deformation, which contributes to the formation of high-angle grain boundaries. ${ }^{4-6}$ UFG materials are characterized by an increased complexity of mechanical, physical and operational characteristics. ${ }^{7-10}$ The main ones include properties such as tensile strength, yield strength under tension or compression, hardness, microhardness, corrosion resistance, and others. ${ }^{11,12}$ The most developed methods of implementing SPD are the ECAP and high-pressure torsion. To implement the ECAP, a tool

*Corresponding author's e-mail:

vi-ta.z@mail.ru (Violetta Andreyachshenko) with a $90-150^{\circ}$ angle is used. The authors of the majority of studies dealing with the ECAP noted intense hardening, resulting from the implementation of the first deformation cycle. However, with the increasing degree of accumulated strain, decreasing intensity of hardening was observed, with a general increase in mechanical properties. $^{13-15}$

The route of deformation has a decisive effect on the microstructure evolution in the process of deformation. In reference studies, ${ }^{16,17}$ it is noted that the $\mathrm{C}$ route has the best effect during the ECAP. On the other hand, the authors of reference ${ }^{18}$ noted that a smaller grain size of ECAP samples was obtained along the $\mathrm{Bc}$ route. According to the diagram presented in reference, ${ }^{19}$ the metal fibres return to their original state as a result of two deformation cycles along the $\mathrm{C}$ route, and only four treatments on the $\mathrm{Bc}$ route. Thus, a change in the direction of the metal flow along the $\mathrm{C}$ route occurs at each 
turning of a sample, ensuring a non-monotonic deformation. In this case, given that the metal is in the plastic state, a reversible motion of dislocations is impossible, as in the case of the elastic state, while on the Bc route, changing the direction of the metal flow is more smooth. The limitation of the possible number of deformation cycles depends on the occurrence of cracks in ECAP specimens.

Alloys from series AA-2xxx are characterized by thermal and strain hardening. As a rule, dispersoids and dispersed particles of the $\theta-\mathrm{A} 12 \mathrm{Cu}$ phase act as the hardening phases in alloys from the $\mathrm{Al}-\mathrm{Cu}$ series. ${ }^{20} \mathrm{In}$ reference ${ }^{21}$ it is noted that during the ECAP treatment of aluminium alloys, dynamic aging proceeds, which also contributes to the alloy hardening. Alloy AA2030 is of great interest since its composition includes $\mathrm{Pb}$. The introduction of $\mathrm{Pb}$ into the composition of aluminium alloys provides for easier cutting that is an important feature of deformable aluminium alloys used in mechanical engineering. However, in the technical literature there is not enough information about the effect of SPD on the deformation behaviour of $\mathrm{Pb}$-containing aluminium alloys. This research deals with analysing the ECAP effect on the microstructure and mechanical properties of the AA2030 alloy.

\section{EXPERIMENTAL PART}

As the material for studying, the AA2030 alloy with composition Al-3.89Cu-1.25Pb-0.8Mg-0.55Mn-0.31Fe$0.2 \mathrm{Si}$ was used. There were rods with a diameter of 30 $\mathrm{mm}$ and a length of $100 \mathrm{~mm}$. Before the ECAP treatment, annealing was carried out in a chamber electric furnace under air atmosphere, at a temperature of $480{ }^{\circ} \mathrm{C}$ and a dwell time of up to 40 minutes. The ECAP was carried out at room temperature in a $105^{\circ}$-instrument with a plunger speed of $5 \mathrm{~mm} \cdot \mathrm{s}^{-1}$. During the ECAP, routes $\mathrm{Bc}$ and $\mathrm{C}$ were used. Natural aging was carried out at room temperature within 45 months.

The chemical composition was determined using a SPECTROMAx instrument. The microstructure was characterized with an Olimpus light microscope and a JSM 6490LV scanning electron microscope on transverse and longitudinal microsections. A JEM 2100 transmission electron microscope was used to study the fine structure. The types of inclusions were identified with energy dispersive spectroscopy (an EDS analysis), using both SEM and TEM. Mechanical properties were determined with a tensile test made on flat samples of the short type.

\section{RESULTS AND DISCUSSION}

\subsection{Microstructure evolution in the ECAP treatment}

After annealing, the grain size was $4 \pm 1.5 \mu \mathrm{m} . \mathrm{Pb}$ in the alloy was mainly present as the $\mathrm{A} 113 \mathrm{~Pb} 10 \mathrm{O} 7 \mathrm{Cu}$ oxide, and its formula was determined on the basis of the stoichiometric composition of the inclusions. There were also $\theta$ and $(\mathrm{Fe}, \mathrm{Mn}) \mathrm{xSi}(\mathrm{Al}, \mathrm{Cu}) \mathrm{y}$ phases. In the $(\mathrm{Fe}, \mathrm{Mn}) \mathrm{xSi}(\mathrm{Al}, \mathrm{Cu}) \mathrm{y}$ phase, $\mathrm{Fe}$ and $\mathrm{Mn}$ atoms mutually replaced each other, which was in agreement with the results obtained in reference ${ }^{22} . \mathrm{Mg}, \mathrm{Mn}$, and $\mathrm{Cu}$ were dissolved in the main matrix; we did not find any Mg-containing inclusions. $\mathrm{Si}, \mathrm{Fe}$, and $\mathrm{Pb}$ were completely bound to intermetallic inclusions and not detected in the main matrix. It should be noted that the deformation route did not have a noticeable effect on the distribution pattern and composition of the inclusions detected with SEM. However, the C route led to a more intense refining of the intermetallic particles. The nature of the distribution of inclusions after four deformation cycles along both routes is shown in Figure 1.

Figure 2 shows a dark-field image of the microstructure after four cycles of deformation, typical for the ECAP-treated aluminum alloys. For both routes, a strong fragmentation of the microstructure is found together with the formation of a grain/subgrain structure. The average grain size after four cycles of the ECAP is $420 \mathrm{~nm}$ for the samples treated along the $\mathrm{Bc}$ route and $380 \mathrm{~nm}$ for the samples treated along the $\mathrm{C}$ route. The grain boundaries are mostly non-equilibrium, with
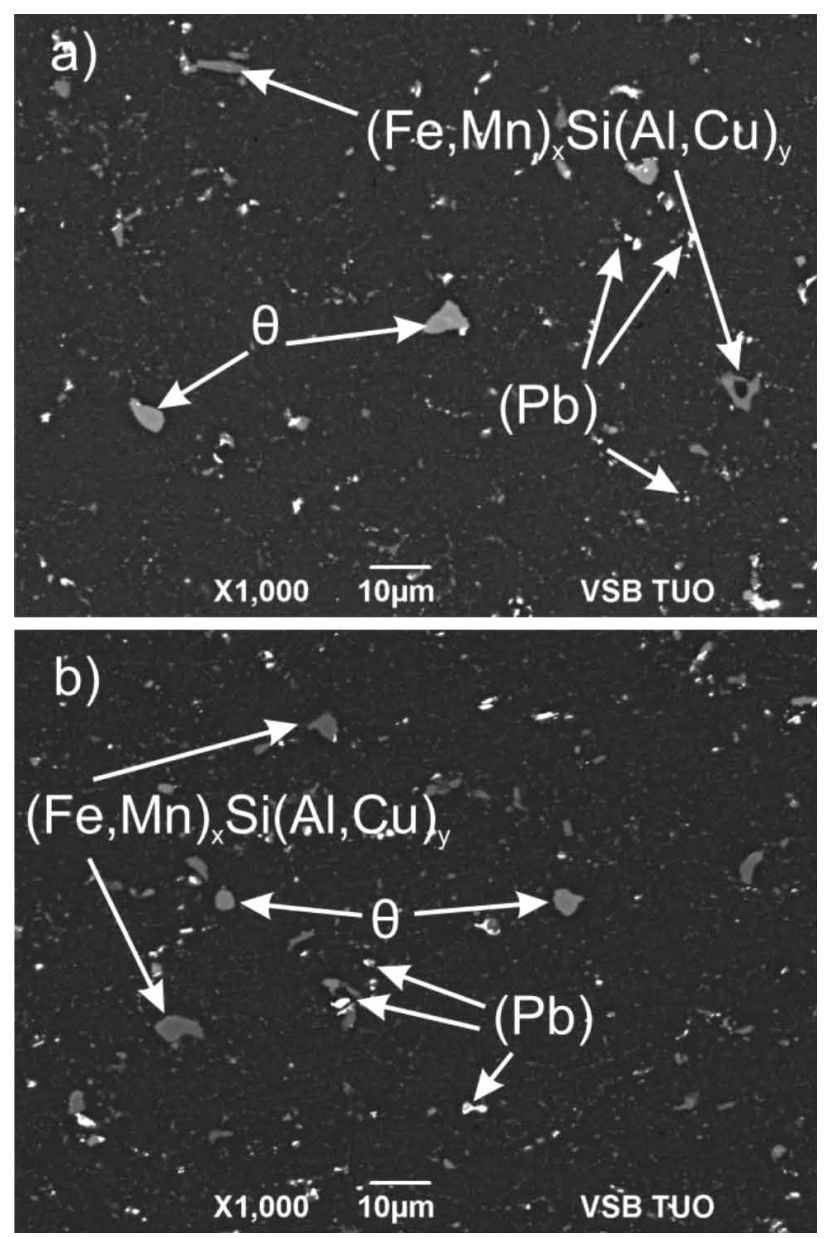

Figure 1: Morphology and distribution pattern of inclusions after four cycles of deformation: a) along the $\mathrm{Bc}$ route and b) $\mathrm{C}$ route 

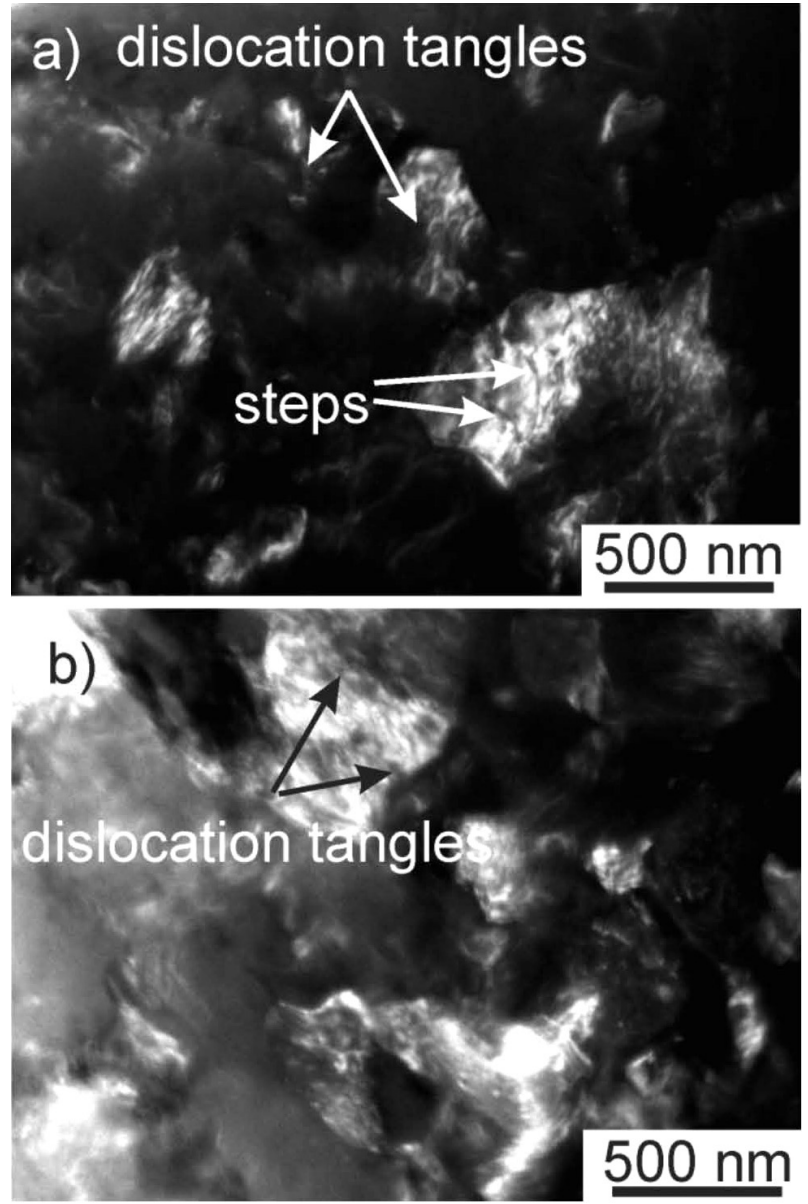

Figure 2: Dark-field images of the microstructures after four cycles of deformation: a) along the $\mathrm{Bc}$ route and b) $\mathrm{C}$ route

significant internal stresses. The grain structure is bimodal, i.e., there are both grains practically free of dislocations, and grains with an increased density of dislocations. For the latter, the formation of coils of dislocations, dislocation walls, steps and subgrain boundaries is characteristic.

Rod-shaped inclusions of the $\mathrm{Al} 7 \mathrm{Cu} 3 \mathrm{Fe}$ phase are located along the grain boundaries. The rod-shaped particles are observed either along or across the grain boundaries. Such locations of the particles probably have a strengthening effect on the alloy, contributing to the pinning of the grain boundaries. In addition to the rod-shaped inclusions, effective breaking of the grain boundaries is provided by dispersoids with an A120Cu2Mn3 compound. The $\theta$-phase has a less noticeable effect when the grain boundaries move, and there are inclusions of various degrees of coherence, from semi-coherent to coherent with a bright diffraction contrast. Particles of the $\theta$-phase are often located at the junction of three or more grains, which suggests a stimulating effect on the process of refining the grains. A similar effect was found in reference ${ }^{23}$.

\subsection{Aging effect on the deformed microstructure}

As a result of prolonged natural aging, the microstructure is stabilized. The internal stresses decrease, and the dislocation redistribution occurs. A transformation of dislocation walls into subgrain boundaries is observed. In addition, in the studied microstructure, high-angle grain boundaries free of boundary dislocations are found. The grain boundaries are mostly equilibrium, thin and without the moire contrast, which is attributed to the high-angle grain boundaries (Figure 3). However, non-equilibrium grain boundaries are also present in the metal structure. As a rule, such boundaries are inherent to large grains with sizes of up to 1 micron.

Another characteristic of the microstructure after the prolonged natural aging is also the fragmentation of large grains with non-equilibrium boundaries into subgrains with sizes of 100-300 nm. It should be noted that we found grains that preserve the cellular structure with a bright diffraction contrast. In general, the microstructure of the alloy after aging had a lower dislocation density, both in the grain body and in the boundary areas. Thus, our results are consistent with the grain refinement found during the aging process of the ECAP-treated samples and reported in reference ${ }^{24}$. The formation of a
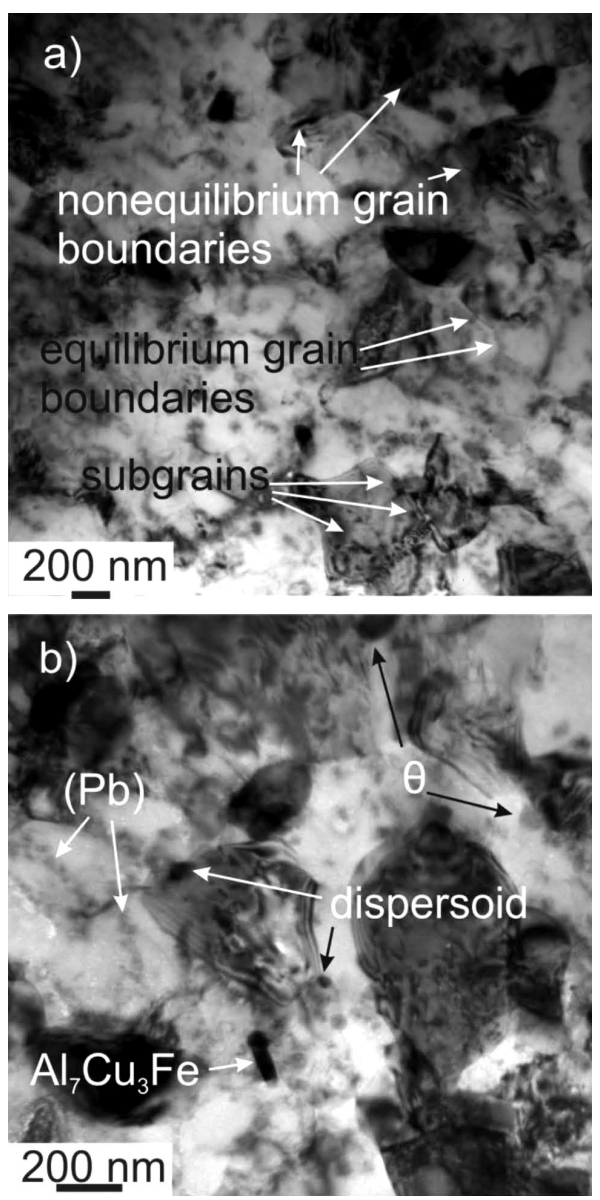

Figure 3: Alloy structure after: a) prolonged aging and b) morphology of inclusions 
large number of dispersed $\mathrm{A} 120 \mathrm{Cu} 2 \mathrm{Mn} 3$ particles, mainly located along the grain boundaries but also present in the body of a grain, is observed. No long rod-shaped particles are observed, but short rod-like inclusions, up to $150 \mathrm{~nm}$ long, are present. In the process of aging, a gradual dissolution of the $\theta$-phase occurs; it is accompanied by several blurred outlines of inclusions and a deviation of the composition with the formation of $\mathrm{Al}(2.5-6) \mathrm{Cu}$ inclusions. Such a behaviour of the $\theta$-phase particles agrees well with the results obtained with reference studies ${ }^{25,26}$. In our work, no precipitation of the $\theta$-phase along the grain boundaries is recorded. In addition, aging led to the formation of cloud-like lead-containing sections throughout the samples. The sections are discrete, weakly connected with each other, having randomly distributed complex oxides. No dense accumulations of cloudy discharge are observed. As in just ECAP-treated samples, because of the prolonged aging, no $\mathrm{Mg}$-containing inclusions are detected; $\mathrm{Mg}$ remains dissolved in the basic aluminium matrix.

\subsection{Mechanical properties of the ECAP-treated specimens}

Intense hardening of the AA2030 alloy is observed already after the first cycle of the ECAP treatment (Table 1). With the increasing accumulation degree of deformation, further hardening of the alloy is observed, but it occurs less intensely. Compared with the annealed condition after the first cycle of deformation of the alloy, a sharp increase in the strength by $44 \%$ is revealed. However, comparing the result after three cycles with the annealed state, we find that there is a $54-\%$ hardening along the $\mathrm{Bc}$ route and $60-\%$ hardening along the $\mathrm{C}$ route. In addition, a proportional increase in the microhardness is noted. After the first cycle, the microhardness increases by $98 \%$, but further increase in the microhardness after three deformation cycles is equal to $20 \%$ and $7.6 \%$ along the $\mathrm{Bc}$ and $\mathrm{C}$ routes, respectively.

Table 1: Mechanical properties of the aluminium alloy after the ECAP treatment

\begin{tabular}{|l|c|c|c|c|c|c|}
\hline $\begin{array}{c}\text { ECAP cycle and } \\
\text { route }\end{array}$ & $\begin{array}{c}\text { After } \\
\text { anneal- } \\
\text { ing }\end{array}$ & $\begin{array}{c}1 \\
\text { cycle }\end{array}$ & $\begin{array}{c}3 \\
\text { cycles, } \\
\text { Bc }\end{array}$ & $\begin{array}{c}4 \\
\text { cycles, } \\
\text { Bc }\end{array}$ & $\begin{array}{c}3 \\
\text { cycles, } \\
\text { C }\end{array}$ & $\begin{array}{c}4 \\
\text { cycles, } \\
\text { C }\end{array}$ \\
\hline Strength, MPa & 194.86 & 280.3 & 300.82 & 215.85 & 312.12 & 290.8 \\
\hline $\begin{array}{l}\text { Relative residual } \\
\text { elongation, \% }\end{array}$ & 4.2 & 4.7 & 5.5 & 4.1 & 5.7 & 4.4 \\
\hline $\begin{array}{l}\text { Microhardness, } \\
\text { HV }\end{array}$ & 68.4 & 135.3 & 162.8 & 129.7 & 145.6 & 105.1 \\
\hline
\end{tabular}

The overall increase in the microhardness is $138 \%$ for the samples treated along the $\mathrm{Bc}$ route and $113 \%$ for the samples obtained from the $\mathrm{C}$ route. The lower intensification of particle dissolution during the deformation on the $\mathrm{Bc}$ route probably contributes to higher microhardness values upon deformation along this route. However, the $\mathrm{C}$ route is characterized by higher values of both the tensile strength and the relative elongation under tension. The hardening-intensity drop with the increasing accumulation degree of deformation is probably due to the saturation of the microstructure with dislocations and the lag in the rate of conversion of subgrain boundaries and dislocation walls into high-angle grain boundaries.

This is also evidenced by the fact from the TEM analysis of the structure evolution as a result of the ECAP that non-equilibrium grain boundaries with a high dislocation density were mainly observed, while natural aging led to a purification of the grains due to dislocations and transformation of non-equilibrium grain boundaries into equilibrium ones.

It should be noted that for both routes there is a slight decrease in the strength and ductile properties after four ECAP cycles. This is due to the formation of cracks on the specimens in the process of deformation. On the samples treated with three ECAP cycles, small cracks are visible in the areas along the workpiece length. After four deformation cycles, small cracks spread along the entire length of the workpiece, and in the boundary areas, the cracks penetrate $1 / 2$ or $2 / 3$ of the workpiece diameter. This leads to a general decrease in the mechanical characteristics of the samples treated along both routes.

Thus, the maximum value of the tensile strength of the aluminum alloy is achieved after the third cycle of the ECAP while the longitudinal axis is turned around by $180^{\circ}$ after each deformation cycle. Based on the same deformation pattern, the maximum elongation is also observed and it achieves $5.7 \%$.

Intense hardening of the alloy is affected by the refinement of the grains during the ECAP process, as well as the dispersion hardening due to the inclusions detected with the TEM analysis. In the ECAP, dynamic aging of the alloy takes place, during which an intensification of dispersoids is observed. In addition, the selection of dispersoids actively proceeds throughout the entire process of deformation. Given that the ECAP is carried out on pre-annealed samples, the solid solution is not oversaturated. The formation and growth of dispersed particles occur as a result of intense mixing of metal layers during the deformation. The mixing of the metal contributes to the partial dissolution of large inclusions observed in the annealed samples. A local increase in the concentration of dissolved alloying elements contributes to the nucleation and growth of dispersed particles during the ECAP; thus, the process of dynamic aging of the alloy is realized.

Grain refinement makes a significant contribution to the alloy hardening, but this process competes with cracking during the deformation. This results in decreased mechanical characteristics after the four cycles of the ECAP, despite the formation of an ultrafine-grain structure.

Thus, when deformation is carried out along the $\mathrm{C}$ route, higher mechanical properties are obtained. This increase is caused by the transformation of long rod- 
shaped inclusions into more favourable short rod-like inclusions. On the other hand, when deformation is carried out along the $\mathrm{C}$ route, finer grains are obtained, helping to improve the complexity of the alloy mechanical characteristics.

\section{CONCLUSIONS}

In this study, we carried out a TEM analysis of the microstructure evolution of the AA2030 aluminium alloy treated with the ECAP under the conditions of dynamic aging after preliminary annealing, as well as prolonged natural aging. We studied the effect of the ECAP on the alloy mechanical properties and made the following conclusions:

1. The ECAP contributes to dynamic aging that is accompanied by the formation of $\mathrm{A} 120 \mathrm{Cu} 2 \mathrm{Mn} 3$ dispersoids.

2. Prolonged natural aging causes an increase in the number of $\mathrm{A} 120 \mathrm{Cu} 2 \mathrm{Mn} 3$ dispersoids and a partial dissolution of the $\theta$-phase with the formation of inclusions with the $\mathrm{Al}(2.5-6) \mathrm{Cu}$ composition. In addition, with aging, a transformation of long rod-shaped inclusions into more favourable short ones with a length of up to $150 \mathrm{~nm}$ is observed.

3. The deformation along the $\mathrm{C}$ route provides for higher mechanical characteristics, based on a more substantial refining of the grains.

4. As a result of the ECAP implementation, an ultrafine-grain structure with a grain size of less than 420 $\mathrm{nm}$ is obtained.

5. Processing is carried out in three cycles of deformation since the implementation of four cycles leads to embrittlement of the metal and the formation of cracks on the samples.

\section{Acknowledgment}

The authors thank the head of department at the VSB - Technical University of Ostrava - prof. Vlastimil Vodárek for his assistance with the EDS analysis.

\section{REFERENCES}

${ }^{1}$ C. G. Figueroa, R. Schouwenaars, J. Cortés-Pérez, R. Petrov, L. Kestens, Ultrafine gradient microstructure induced by severe plastic deformation under sliding contact conditions in copper, Materials Characterization, 138 (2018), 263-273, doi:10.1016/j.matchar.2018. 02.017

${ }^{2}$ S. Sabbaghianrad, S. A. Torbati-Sarraf, T. G. Langdon, An investigation of the limits of grain refinement after processing by a combination of severe plastic deformation techniques: A comparison of $\mathrm{Al}$ and $\mathrm{Mg}$ alloys, Materials Science and Engineering: A, 712 (2018), 373-379, doi:10.1016/j.msea.2017.11.090

${ }^{3}$ V. Segal, Modes and Processes of Severe Plastic Deformation, Materials, 11 (2018), 1175, doi:10.20944/preprints201807.0050.v1

${ }^{4}$ F. Samadpour, G. Faraji, P. Babaie, S. R. Bewsher, M. Mohammadpour, Hydrostatic cyclic expansion extrusion (HCEE) as a novel severe plastic deformation process for producing long nanostructured metals, Materials Science and Engineering: A, 718 (2018), 412-417, doi:10.1016/j.msea.2018.01.116

${ }^{5}$ W. H. El-Garaihy, D. M. Fouad, H. G. Salem, Multi-channel spiral twist extrusion (MCSTE): A novel severe plastic deformation technique for grain refinement, Metallurgical and Materials Transactions A, (2018), 1-11

${ }^{6}$ V. A. Andreyachshenko, Finite element simulation (FES) of the fullering in device with movable elements, Metalurgija, 55 (2016) 4 , 829-831

${ }^{7}$ V. A. Andreyachshenko, A. B. Naizabekov, Microstructural and mechanical characteristics of AlSiMnFe alloy processed by equal channel angular pressing, Metalurgija, 55 (2016) 3, 353-356

${ }^{8}$ A. B. Naizabekov, V. A. Andreyachshenko, Evaluation of possible mechanical property improvement for alloy of the $\mathrm{Al}-\mathrm{Fe}-\mathrm{Si}-\mathrm{Mn}$ system by equal-channel angular pressing, Metallurgist, 57 (2013) 1-2, 159-163, doi:10.1007/s11015-013-9706-0

${ }^{9}$ V. Andreyachshenko, A. Naizabekov, The technology of equal channel angle backpressure extrusion for deformation iron and aluminium alloys, Proc. of the $3^{\text {rd }}$ Inter. Conf. on NANOCON 2011, Brno, Czech Republic, 2011, 246-252

${ }^{10}$ A. Naizabekov, V. Andreyachshenko, J. Kliber, Forming of microstructure of the Al-Si-Fe-Mn system alloy by equal channel angular pressing with backpressure, Proc. of the $21^{\text {st }}$ Inter. Conf. on Metallurgy and Materials, Metal 2012, Brno, Czech Republic, 2012, 391-395

${ }^{11}$ T. Koizumi, M. Kuroda, Grain size effects in aluminum processed by severe plastic deformation, Materials Science and Engineering: A, 710 (2018), 300-308, doi:10.1016/j.msea.2017.10.077

${ }^{12}$ A. E. Medvedev, M. Y. Murashkin, N. A. Enikeev, R. Z. Valiev, P. D. Hodgson, R. Lapovok, Optimization of strength-electrical conductivity properties in $\mathrm{Al}-2 \mathrm{Fe}$ Alloy by severe plastic deformation and heat treatment, Advanced Engineering Materials, 20 (2018) 3, 1700867, doi:10.1002/adem.201700867

${ }^{13}$ M. Wroński, K. Wierzbanowski, D. Wojtas, E. Szyfner, R. Z. Valiev, J. Kawałko, K. Berent, K. Sztwiertnia, Microstructure, texture and mechanical properties of titanium grade 2 processed by ECAP (route C), Metals and Materials International, 24 (2018) 4, 802-814

${ }^{14}$ M. Howeyze, A. R. Eivani, H. Arabi, H. R. Jafarian, Effects of deformation routes on the evolution of microstructure, texture and tensile properties of AA5052 aluminum alloy, Materials Science and Engineering: A, 732 (2018), 120-128

${ }^{15}$ H. H. Lee, W. Kim, K. C. Jung, S. Seo, J. K. Lee, H. L. Park, K.-T. Park, H. S. Kim, Circumferential twisting during route B equalchannel angular pressing, Journal of Materials Processing Technology, 259 (2018), 305-311

${ }^{16}$ M. S. Arun, U. Chakkingal, Workability limits of magnesium alloy AZ31B subjected to equal channel angular pressing, Journal of Materials Engineering and Performance, 27 (2018) 3, 1352-1360

${ }^{17}$ P. M. Keshtiban, R. A. Behnagh, V. Alimirzaloo, Routes investigation in equal channel multi-angular pressing process of UFG Al-3\% $\mathrm{Mg}$ alloy strips, Transactions of the Indian Institute of Metals, 71 (2018) 3, 659-664

${ }^{18}$ K. Máthis, M. Köver, J. Stráská, Z. Trojanová, J. Džugan, K. Halmešová, Micro-tensile behavior of Mg-Al-Zn alloy processed by equal channel angular pressing (ECAP), Materials, 11 (2018) 9, 1644

${ }^{19}$ L. B. Tong, M. Y. Zheng, X. S. Hu, K. Wu, S. W. Xu, S. Kamado, Y. Kojima, Influence of ECAP routes on microstructure and mechanical properties of $\mathrm{Mg}-\mathrm{Zn}-\mathrm{Ca}$ alloy, Materials Science and Engineering: A, 527 (2010) 16-17, 4250-4256

${ }^{20}$ J. E. Hatch, Aluminium: properties and physical metallurgy, ASM International 1984, 424, doi: 10.1361/apapm1984p001

${ }^{21}$ H. J. Roven, L. Manping, J. C. Werenskiold, Dynamic precipitation during severe plastic deformation of an $\mathrm{Al}-\mathrm{Mg}-\mathrm{Si}$ aluminium alloy, Materials Science and Engineering: A, 483 (2008), 54-58

${ }^{22}$ L. F. Mondolfo, Manganese in aluminium alloys, The Manganese Center, Paris 1978, 971 
${ }^{23}$ P. Szczygiel, H. J. Roven, O. Reiso, On the effect of SPD on recycled experimental aluminium alloys: Nanostructures, particle break-up and properties, Materials Science and Engineering: A, 410 (2005), 261-264

${ }^{24}$ Z. Yang, A. Ma, H. Liu, J. Sun, D. Song, C. Wang, Y. Yuan, J. Jiang, Multimodal microstructure and mechanical properties of AZ91 Mg alloy prepared by equal channel angular pressing plus aging, Metals, 8 (2018) 10, 763, doi: 10.3390/met8100763

${ }^{25}$ A. Deschamps, F. De Geuser, Z. Horita, S. Lee, G. Renou, Precipitation kinetics in a severely plastically deformed 7075 aluminium alloy, Acta Materialia, 66 (2014), 105-117

${ }^{26}$ Z. Liu, S. Bai, X. Zhou, Y. Gu, On strain-induced dissolution of $\theta^{\prime}$ and $\theta$ particles in $\mathrm{Al}-\mathrm{Cu}$ binary alloy during equal channel angular pressing, Materials Science and Engineering: A, 528 (2011) 6, $2217-2222$ 